Please do not remove this page

RMIT

UNIVERSITY

\title{
De-risking development of medium density housing to improve housing affordability and boost supply
}

Sharam, Andrea; Bryant, Lyndall; Alves, Thomas

https://researchrepository.rmit.edu.au/esploro/outputs/9921858713001341/filesAndLinks?institution=61RMIT_INST\&index=null

Sharam, A., Bryant, L., \& Alves, T. (2015). De-risking development of medium density housing to improve housing affordability and boost supply. Australian Planner, 52(3), 210-218.

https://doi.org/10.1080/07293682.2015.1034146

Document Version: Accepted Manuscript

Published Version: https://doi.org/10.1080/07293682.2015.1034146

Repository homepage: https://researchrepository.rmit.edu.au

(C) 2015 Taylor \&amp; Francis

Downloaded On 2023/04/26 21:42:30 +1000

Please do not remove this page 
Thank you for downloading this document from the RMIT Research Repository.

The RMIT Research Repository is an open access database showcasing the research outputs of RMIT University researchers.

RMIT Research Repository: http://researchbank.rmit.edu.au/

\section{Citation:}

Sharam, A, Bryant, L and Alves, T 2015, 'De-risking development of medium density housing to improve housing affordability and boost supply', Australian Planner, vol. 52, no. 3, pp. 210-218.

See this record in the RMIT Research Repository at:

https://researchbank.rmit.edu.au/view/rmit:47009

Version: Accepted Manuscript

Copyright Statement:

(C) 2015 Taylor \& Francis

Link to Published Version:

https://dx.doi.org/10.1080/07293682.2015.1034146 


\title{
De-risking development of medium density housing to improve housing affordability and boost supply
}

\author{
Authors: Andrea Sharam ${ }^{1}$, Lyndall Bryant ${ }^{2}$, Tom Alves ${ }^{3}$
}

\begin{abstract}
Housing price inflation is a national concern given the serious decline in the number of low- and middle-income households able to purchase housing. In addition housing supply lags well behind demand. In Melbourne, urban consolidation policies explicitly seek intensification to promote housing supply but planning regulation is often criticised for being a significant cost driver for medium density housing. It is assumed that easing supply constraints will improve affordability. We suggest that laissez-faire planning exacerbates affordability issues because this approach fails to address the basic economic problem: the current inability of the market to efficiently match supply and demand in order to progress an orderly and de-risked development process. The role of 'exchange' one of the four housing market sub-systems identified by Burke has until recently generally been ignored but our examination reveals significant economic transaction costs that manifest as development risks that impact on affordability. Fortunately these can be mitigated, but only if there is a more consumer-driven supply response.
\end{abstract}

Key words: housing supply; housing affordability; residential development; planning; medium density housing

\section{INTRODUCTION}

Melbourne has experienced a long period of housing price inflation coupled with a chronic undersupply of new housing stock, which has resulted in a serious decline in housing affordability for low and middle income households (NHSC, 2013). Policymakers have supported urban consolidation, in part to address these issues (Adams, 2009; Goodman et al., 2010; Newton and Glackin, 2014) however intensification has often not occurred where it has been sought and where it has, it is frequently seen as being over-development (Woodcock et al. 2011). Moreover, there has been no improvement in affordability (MCU, 2010; Rowley and Phibbs, 2012), and what has been provided has been criticised for poor quality and design (Newton and Glackin, 2014). Why the market tends to deliver generic apartments of poor quality and design, which are uncompetitive with lower density housing and amenity despite planning objectives, is the topic of this paper.

There is surprising little research that has investigated housing production in Australia (Dowling, 2005; Dalton et al., 2013), with Rowley and Phibbs (2012) the only attempt to date to systematically review the production of medium density housing. Daly's (1982) in depth examination of the 1960s property boom in Sydney provides a rich source of material on the institutions and actors involved with apartment building at that time and this work remains relevant today. Again reflecting that period and its ongoing impact, Clark's (2002) biography of Lend Lease founder Dick Dusseldorp provides valuable historical detail on the introduction of strata title which,

\footnotetext{
${ }^{1}$ Institute for Social Research, Swinburne University of Technology, Hawthorne, Victoria, Australia

${ }^{2}$ Property Economics, Science and Engineering Faculty, Queensland University of Technology, Brisbane, Queensland, Australia

${ }^{3}$ Office of the Victorian Government Architect, Melbourne, Victoria, Australia
} 
enabled the expansion of medium density housing through sub-dividing airspace.

There is a small body of critical literature on developers. Dowling (2005) and Coiacetto (2006, 2009) have examined concentration of firms within the development industry; Ruming (2010) the relationships between developers and local government planners and the impact on planning decisions in Sydney; and Coiacetto developer behaviour in relation to place (Coiacetto, 2000); urban space (Coiacetto, 2007b); and sub-markets (Coiacetto, 2007a).

There is an absence of critical literature for residential development finance, a gap only recently started to be filled by Bryant (2012) and Rowley et al., (2014). There is however is a property development and project finance literature produced for teaching purposes (eg. Weerasooria, 1998; Weaver and Kingsley, 2001; Wilkinson, 2008, Cadman and Topping, 1995, Coiacetto, 2012), or as practice guides (eg. Millington, 2000, Forlee, 2012, Peiser and Hamilton, 2012). These cover numerous forms of development with limited attention to the specifics of medium density housing with Thomas (2010), Coiacetto (2012) and Forlee (2012) addressing the Australian context, although there is also a grey literature produced with the industry in mind (Burke and Associates 2010; Kent, 2011).

Planning as a key input into housing production has attracted considerable attention regarding its role in inflating housing costs. On one side, industry (UDIA, 2011; PCA 2012) argues planning regulations impose unreasonable costs on developers, and on the other, planners and/or housing researchers such as Gurran et al., (2009) suggest planning makes little difference to costs. Bryant and Eves (2014) argue in relation to developer levies, that there is simply no empirical evidence yet. In addition to planning, taxation (especially negative gearing and capital gains tax), government subsidies (eg rental assistance and first home owner grants), and construction costs have come under scrutiny (UDIA, 2011; Worthington, 2011; Wing, Norman and Orsmond, 2012; Rowley and Phibbs, 2012; PCA 2012; Urbis, 2012; Burke, 2012; HSAR, 2012; Williams and Macken, 2012) although much of this work does not specifically consider medium density infill.

A key assumption is that housing production cost savings should translate into lower housing prices. Rowley and Phibbs (2012) and Rowley et al. (2014) argue for reducing risk and costs for developers as a means of lowering prices and thereby improving affordability. Rowley et al., (2014) found (reflecting the teaching and practice literature) that housing production cost is relevant to project viability but they were unable to articulate is why developers would put their product onto the market below prevailing prices unless they were obliged to by government in cases where that government had provided subsidies or guarantees. Production costs may be an issue but housing asset inflation is driven by the availability of investment finance, increased consumer capacity to borrow, and competition between consumers for well-located housing (2012) and by property speculation. Woodcock et al., 2011). Viewed through the prism of Burke's housing sub-systems approach (production, consumption, management and exchange) much housing research focuses on production (albeit not much on medium density), consumption, and management (particularly social housing systems), but little attention is given to exchange. Exchange involves

the practices and institutions which facilitate the sale, purchase and renting of housing, with the principal actors here being finance institutions in their many forms, and real estate practitioners. Both are important as facilitative agents in making the development, sales and purchases process possible (Burke 2012:46).

The literature reveals a very substantial gap in regard to exchange. This article begins to fill that gap by examining exchange from a classical economic perspective in relation to multi-unit housing and in particular to strata title of cubic airspace, revealing exchange as a key development risk; one that institutions struggle to address. We argue a basic economic understanding of the market fundamentals has been missing from the debate: the problems of supply and affordability of medium density infill housing relate to the current inability of the market to efficiently match supply and demand in order to progress an orderly and de-risked development process. 
The remainder of this paper begins by outlining the current structures of housing provision for medium density infill housing in Melbourne. This is followed, in Section 3 with a discussion of how the most critical issue for the market, the problem of uncertain consumer demand is addressed. In Section 4 we look at planning policy and its role in bridging the problem. What can be done to reduce demand risk and hence improve affordability is addressed in Section 5 . Conclusions are drawn in Section 6.

\section{STRUCTURES OF HOUSING PROVISION FOR MEDIUM DENSITY HOUSING DEVELOPMENT}

Ball (2003: 914) argues 'differences in institutional structures affect supply responses', and that it is essential to locate the supply system in time and place and understand both actors and institutions (Ball et al., 1988).

A structure of housing provision specifies the nature of the social agents involved in the provision of a particular form of housing and their interlinkages. Producer, consumers and financiers in different guises all have their place within structures of provision (Ball et. al., 1988: 29 - 30).

For medium density housing in Melbourne the key agents and institutions are: developers (producers), apartments buyers, being owner-occupiers or investors (consumers), development and mortgage financiers (finance), strategic and statutory planning, building codes, taxation, consumer law (regulation), land form, spatial relationships (geography), construction types and costs (technology), Victorian and Commonwealth government policies and actions, lobby groups, resident action groups (political). A significant and often overlooked input into production is land supply and landowners are hence also influential agents (land owners).

In examining medium density infill developments (ranging from a few attached single story dwellings to high-rise towers) commonalities and differences can be observed. The most significant divergence to be noted is that developments generally either involve sub-division of land or subdivision of airspace. As can be expected there is a spatial element that reflects zoning and allowable densities but we argue it is also reflects the structures of housing provision.

Medium density developments based on land sub-division generally involve small to medium scale 'infill' sites mostly on large residential blocks that are sub-divided into smaller lots on which single dwellings of between one and three storeys are built (Phan et al., 2008). These new homes may be attached or detached dwellings. The producers of these smaller developments are frequently novices and/or 'Mums and Dads' (Ruming, 2010) or 'part-time developers' (Forlee, 2012: 61). In contrast, larger projects of up to 30 dwellings (Ruming, 2010) involve 'full-time professionals' (Forlee, 2012). This small scale infill form of development is notable for being highly competitive with low margins (Chandler, 2009) making use of the same construction technologies and business structures as detached house builders, and relying heavily on non-unionised subcontracted trades and labour. While this form of development has made a not inconsiderable contribution to new supply (Szafraniec and Hollaway, 2012), it is criticised for poor quality and design (Newton and Glackin, 2014), without providing more affordable housing. Alternatively, such sites in high demand locations are developed with premium stand-alone small lot housing product, providing only marginal density gains and pricing out all but the wealthy.

The relative small scale of such projects impacts on their ability to access development finance. In the land-subdivision medium density development model, the land is used as security against borrowings and the quantum and characteristics of the loan reflects the underlying un-subdivided value of the site rather than the total anticipated cost or value of the project. This means that the requisite construction loans are often secured against other assets of the borrower such as the family home (Weaver and Kingsley, 2001). The asset backing of the borrower therefore limits how much can be borrowed and thus the scale of the project able to be undertaken. Smaller scale projects are often seen as lower risk by financiers by virtue of needing fewer buyers to generate 
the income to repay the loan, the relatively short project time frames and the intrinsic (and realisable) value in the underlying land should the financier need to sell assets to recoup its loan. These are uncomplicated loan structures, generally negotiated at a local bank branch level. This mainstream bank finance has replaced solicitor's funds used during the 1960s and 1970s for the building of flats (Burke 2012).

On the other hand, projects that sub-divide airspace are by definition multi-storey complexes, with apartments on each level. Developers of such projects tend to have corporate business structures; professional staff and many operate on a regional level, and some on a national level (Dowling, 2005). Much of the product is aimed either at the luxury end of the market (where greater margins are available) or investors seeking rental yields in the short term and capital gain in the longer term. Both these market segments are strongly influenced by geography and amenity, with landlords requiring a ready supply of tenants with capacity to pay, inclining them towards the city centre. Tenants for investor stock seek ready access to employment or study nodes as well as entertainment locations so as to minimise transport and other living costs. Upmarket owneroccupiers seek water views, high neighbourhood amenity and so-called 'lifestyle' attractions.

Reflecting diversification out of the non-residential construction sector (Dowling, 2005) these developers use building technologies similar to those employed in commercial developments, often using unionised workforces and operating with higher overheads and margins, reflecting economies of scale. As with the smaller scale development, the development site itself is used as security for the loan that is required to complete the project, however the quantum and conditions of the development finance reflects the anticipated overall cost or value of the project, thus allowing for a substantially larger loan and hence larger project to be constructed. The developer usually provides little personal security for the loans, with loans secured only against the project in many instances, or against other company assets (Weaver and Kingsley, 2001). The financier is concerned with the considerable financial gap between the raw value of the land and the total cost of developing the airspace as the long and often uncertain time period between project inception and completion makes this form of development a relatively high-risk financing venture. As Ball (1998: 1505) notes, it is the lender who bears most of the costs of failure whereas the developer 'reaps virtually all the gain' if 'the gamble comes off'. Although public policy supports this form of development its contribution to supply is mainly through larger towers, with investment low or nonexistent in many suburban activity centres. Much of what has been built is criticised for poor design and quality, is notably uncompetitive when compared to local house prices, and is often ferociously attacked by residents' groups (Woodcock et al., 2011).

We have noted above that the smaller developments are relatively lower risk and hence are financed somewhat differently from the larger developments. This risk relates primarily to the gap between the realisable value of the land and the size of the loan. Development of airspace carries greater risk reflecting greater complexity and the longer time periods for construction. Many of these risks can be mitigated, but not all (such as interest rates affecting buyer's decisions to purchase). The most serious risk in all property development is the difficulty in finding and locking in demand at critical junctures. From a broader economic perspective this is the one risk that is least efficiently mitigated, and is explored further in the following section.

\section{EXCHANGE: SETTLEMENT RISK AND MITIGATION MEASURES}

Larger strata titled developments typically take a number of years from inception to completion, with many critical hurdles along the way (Rowley and Phibbs, 2012, Millington, 2013). Such projects generally receive no revenue at all until completion, at which time the new strata title is created and the transfer of real property (settlement) occurs. This point in time has expended virtually all project funds expended leaving both developer and financiers highly exposed. Unlike greenfield development, apartment buildings generally cannot be staged to deliver incremental

4 In Victoria 'strata title' is simply called a 'lot' under the Sub-division Act 1988 
revenue.

Developers rely on research to determine the strength of demand, and 'pre-sales' are used to confirm market acceptance of the product type and price point on offer. Pre-sales are also sought by financiers to ensure there are sufficient sales at completion to cover repayment of the loan. Funds borrowed for construction are generally not released by the financiers until a minimum number of pre-sales are achieved. Due to strict lender requirements, developers are accordingly very conservative in regard to the type of product they will offer and localities they target as a means of ensuring sales (Kent, 2011).

The importance of pre-sales in the medium density housing development process cannot be overstated. Given construction cannot commence until sufficient pre-sales are achieved, the pre-sale period can stretch into many months or years, making it more time consuming than statutory approval processes. Pre-sale campaigns include: constructing and operating display units; printing of marketing materials; engagement of real estate agents to handle sales; newspaper, magazine, internet, television and radio advertising; home shows and trade delegations. As investors are often the bulk of the purchasers, these are accessed through channels such as the financial planning industry. The commission paid to financial planners is up to $6 \%$ of the purchase price. Pre-sale campaigns cost up to $10 \%$ of project costs, making it more expensive than the finance.

Considerable time can elapse between a pre-sale and settlement, which may correspond to a shift in market conditions and demand. Should market conditions deteriorate, or the buyer's financial position change, buyers who have signed a pre-sale contract may default on their purchase, given they are only legally required to pay a maximum of $10 \%$ of the property price as a deposit at presale, and deposits are held in trust until settlement (Burke and Associates, 2010). Although a presale contract theoretically binds the purchaser, in practice developers sometimes find default at settlement difficult to remedy. Purchasers for example are inclined to 'walk away' if the apartment value falls significantly between pre-sale contract and completion, particularly if mortgage lenders withdraw their offer of finance. This 'settlement risk' is addressed by developers and financiers through a number of means and has had greater focus since the global financial crisis (Bryant, 2012). Financiers vet purchasers to establish whether there is risk of default at settlement, restrict the purchase of multiple dwellings, often to as little as two apartments, and in some cases limit the level of foreign investment (Burke and Associates, 2010). Still, settlement risk is a significant risk factor that cannot be fully mitigated as evidenced in the aftermath of the global financial crisis (Bryant, 2012).

Most important in terms of affordability, projects using debt finance will only proceed if the anticipated return on the investment is assessed by the financier as commensurate with the risks, with a minimum rate of return of 20 per cent on costs currently demanded by the major Australian banks, as senior lenders, in most cases (Kent, 2011). On an annualised basis this return is modest (e.g. a four year project means a return of just under five per cent per annum). Financiers take a margin on the loan and fees rather than share in the profits and are first in line when earnings are disbursed (Burke and Associates, 2010, Bryant 2012). Pre-sales lock in the price early in the project, and if a project is 100 per cent pre-sold (which is often currently required by financiers), the developer does not capture any of the uplift in property values that may have occurred in the intervening period (the buyer does). The developer can only capture lift in value that occurs between purchase of the land and pre-sale. This can be compared with social housing projects, which are de-risked because demand is locked in at the outset and progress payments underpin the process.

Pre-sales therefore represent a sub-optimal solution to the problem of locking in the demand to ensure a project can proceed in the knowledge that settlements will occur at the completion of the project. Policy analysis almost invariably follows the assumption however that if input prices for housing can be lowered, housing would be more affordable; hence the ongoing debate on the role of taxation and planning on housing affordability. This view assumes that housing supply comes onto the market on a cost plus margin basis, whereas new housing stock in fact comes onto the 
market reflecting prevailing prices (Berry, 2010). Cost savings, such as those achieved through construction innovation or planning deregulation accrue to the developer in the absence of robust competition (see Coiacetto, 2009 for a discussion of the oligopoly structure of the industry). Where cost savings are important is in terms of project viability (that is, in ensuring projects are able to attract financing and can thus proceed (Rowley et al., 2014). That nevertheless leaves us with the problem of how housing prices relate to costs, and in the next section we discuss the role of planning in this.

\section{THE ROLE OF PLANNING IN EXACERBATING THE AFFORDABILITY ISSUE}

Victoria has a laissez-faire planning regime, especially in the central city area, which is designed to promote capital investment. Floor space or plot ratios have not existed as a development control tool since 1999, and while building height limits apply in many areas, in practice these are treated in the application process as a negotiable factor. As the market has increasingly sought to invest in residential products, one argument mounted by those with an interest in keeping restrictions on site yield to a minimum is that additional yield will help keep apartments affordable. However, permitting greater yields on redevelopment sites pushes up the price of land in the vicinity, because landholders' expectation of future yield is raised, thus negating any cost saving for future projects. At the same time, existing redevelopment sites tend to go back onto the market as vendors seek to capture the uplift in site value and exit the project in a risk free manner (Woodcock et al., 2011).

Assuming these development sites are purchased by developers genuinely intending to build upon them, the new project proponents often find themselves with sites literally too risky and/or expensive to develop (Rowley and Phibbs, 2012). With the increased yield potential capitalised into the land price, only an additional increase in apartment prices (that is, an increase in the capacity and willingness of consumers to buy) or decrease in construction or other costs will permit the project to be viable and gain finance. A further risk is created by the larger scale of the development, as this limits who will buy into them. Apartments in large towers, for example, are mostly purchased by investors, responding to demand from specific tenant cohorts, such as students. The alternative is for the new owners to land bank their site until demand at the right price point exists.

As we have outlined smaller medium density development is constrained by the limitations on their access to capital. Larger firms have the ability to undertake larger and riskier redevelopments but these not only have higher costs, but the margins sought are also higher. Designated suburban development zones such as Activity Centres should attract larger developments but the price point at which apartments can be supplied does not have a market in many nominated localities (Newton and Glackin, 2014). Those undertaking larger developments do not compete with small developers for suburban residential sites, as these projects are considered too small and margins too slender. Only where yields can be increased significantly (eg through lifting height restrictions substantially) are they likely to be interested. The result of the current structure of housing provision is that planning alone will not deliver desired built forms and uses. But it does have an important role.

While it may appear counter-intuitive, density restrictions in the form of planning controls that limit the yield available from re-development sites, such as height limits, floor space ratios or bedroom quotas, may be effective in dampening speculation and creating a positive environment for more affordable housing development. In essence, planning controls can do the opposite of deregulation by creating certainty: certainty about what the site is capable of yielding. With greater certainty, risk is reduced and the project has an increased likelihood of obtaining finance and proceeding as proposed. Importantly landowners will moderate their expectations of capturing any future uplift in value once the development capability of the site is known and fixed. The need for increased housing supply as well as affordability requires certainty in the planning process to remove speculation from the development process.

Restrictions on yield to prevent over-development on larger infill sites can be offset in 'greyfield' 
suburbs by reconfiguring existing housing lots through aggregation to enable precinct regeneration (Newton and Glackin, 2014). Moderate height increases and the better use of airspace can maximise design outcomes and optimise land use while retaining amenity. Mixed-use developments that incorporate residential over retail or small scale commercial uses can provide important amenity and housing choice. Yet even if the incentives to speculate on land value were removed from the planning scheme, the current development models would still be problematic as the problem of finding buyers and locking them in remains and in part because there is a lack of competition.

\section{HOW CAN THE DEVELOPMENT PROCESS BE DE-RISKED?}

Housing supply innovation requires economic actors who are able to commit to the supply of affordable housing and the most obvious candidates are consumers themselves. The means by which consumers can be involved in innovation is both technical and conceptual. Conceptually, aggregation of consumers is a method of reducing the search costs that currently undermine the efficiency of the market. Aggregation occurs in many markets and is the basis of cooperatives, and traditionally draws on communities of interest, such as with the German Baugruppen (building groups) or baugemeinschaften (building cooperatives).

Baugruppen and baugemeinschaften are essentially 'DIY' syndicates that produce medium density housing for owner-occupiers at around $75 \%$ of the market cost, as they effectively remove the need for the developer, and hence the developer's margin (Alves and London, 2012). Since the 1990s, Baugruppen have come to play a significant role in the provision of medium density housing and the urban regeneration in a number of major city regions across Germany (Krämer and Kuhn, 2009; Fuchs and Orth, 2000). The sector also has a presence in France and the Netherlands. Unlike typical medium density housing developments, dwellings are tailored to suit the diversity of households involved and often embody other collective ambitions, such as higher environmental performance. Once the development is complete, the syndicate disbands and member households become owner-occupiers of their individual dwellings with common aspects of the property managed in the usual way by the equivalent of an owners' corporation (de Maddalena and Schuster, 2005: 44), or the syndicate can remain as an ongoing cooperative to manage the property. Baugruppen effectively aggregate demand prior or close to project conception so are less risky. Baugruppen financially backed by a large community housing organisation as proposed by Common Equity Housing Ltd in Victoria (BCCM \& CEHL 2014) could be a means of delivering larger medium density affordable housing projects. To date there has only been one cooperative medium density development project aimed at owner-occupiers in Australia that has been publicly evaluated, and it found a saving of $28 \%$ (Dolin 1992). Overseas experience and the Australian example suggest further research into 'deliberative' forms of development is warranted.

Ball (2003) suggested game theory may prove to have theoretical application to housing supply. Conceptually and technically, aggregation via the creation of a pool of consumers and pool of suppliers fits with 'market design' a new economic field that has emerged from game theory which, highlights the value of cooperation in markets and the market efficiencies that arise from shifting from bi-lateral trades to aggregation. Given that there are aggregators in the housing development market such as the internet-based service Citiniche, whose founder Ivan Rijavek argues development risk and costs can be reduced and affordability improved by matching housing demand to supply in a more deliberative way (Rijavek, 2013), it would appear that theoretical and empirical housing research is lagging behind practice, although it has been conceptualised by Sharam (2012). There is as yet no major research exploring these ideas or applications.

The issue of aggregation goes to the economic issues encountered by the development process. As important, are the legal issues pertaining to the pre-sale and settlement of apartments. While there have been some changes to the National Consumer Law to provide greater protection to purchasers of apartments there has been no fundamental re-thinking of the legal mechanism. Research is required to understand whether it is possible to achieve law reform that can de-risk the development process for both consumer and developer. But perhaps pre-sales will be overtaken by 
'group apartment auctions', where newly constructed apartments are simultaneously put to auction after the titles are created. Melbourne's first group auction in April 2014 was highly successful despite the lack of stamp duty exemption (Pallisco, 2014). According to game theory and as established in practice in the US this type of auction permits developers to make higher margins. This type of innovation in the market should draw our attention as housing researchers and planners to the housing sub-system involving exchange because it is indicating the current structure of housing provision has critical flaws. Clearly, there is a need for closer collaboration between housing, planning and property sectors.

Finally, landowner speculation can be eased through planning reform but property speculation per se cannot. Property investment for capital gain is currently underwritten by taxpayers in the form of reduced capital gains tax and negative gearing and is justified in policy terms as encouraging supply. The inflationary impacts of these measures have been widely discussed (eg Eslake, 2013). From our perspective investors may be a source of funds for new development but this demand segment is also highly associated with settlement risk. Investors are a source of market volatility, which heightens the development risk.

\section{CONCLUSION}

The failure of public policy to deliver affordable medium density infill housing has variously been laid at the door of the planning system, at taxation policy, and at construction costs. We have shown that planning on its own cannot deliver affordable housing as an outcome; there needs to be a structure of housing provision capable of responding to the housing objectives of the planning scheme. Public policy however exacerbates housing price inflation by facilitating rather than restraining property speculation, thereby affecting project viability, which in turn affects supply and prices.

Examined through an economics lens, the housing exchange sub-system reveals demand as the key risk faced by developers, and this drives institutional responses. Pre-sale contracts have evolved to legally bind consumers to their purchase decision but they are a sub-optimal mechanism. The risks associated with uncertain demand create a barrier to project viability, and lift the threshold profit margins expected by financiers. If this risk was reduced, expectations of the margins required would moderate permitting more projects to proceed. But greater competition is also required to pass on these savings to consumers. Aggregation of buyers offers a more orderly and de-risked development process, and deliberative forms of development provide a muchneeded source of competition, together they would enable more supply of better quality and design at more reasonable prices.

\section{REFERENCES}

Adams, R. 2009. Transforming Australian Cities: For a More Financially Viable and Sustainable Future: Transportation and Urban Design. Melbourne: City of Melbourne and Department of Transport.

Alves, T. and London, G. 2012. "New Housing for a Shifting Urban Paradigm: Housing Development Co-operatives as a More Affordable and Sustainable Alternative for Housing Provision in Australian Cities." Proceedings of the 6th Australasian Housing Researchers' Conference, University of Adelaide, 8-10 February 2012.

Ball, M. 1998. "Institutions in British Property Research: A Review", Urban Studies, 35(9): 15011517.

Ball, M. 2003. "Markets and the structure of the Housebuilding Industry: An International Perspective". Urban Studies, 40(5-6): 897-916.

Ball, M. Harloe, M., and Marten, M. 1988. Housing and Social Change in Europe and the USA, 
London: Routledge.

BCCM (Business Council of Cooperatives and Mutuals) and CEHL (Common Equity Housing Ltd) 2014. Breaking Through the Affordability Ceiling, National Housing Round Table $25^{\text {th }}$ February Melbourne.

Berry, M. 2010. "Housing Wealth and Mortgage Debt in Australia." In The Blackwell Companion to the Economics of Housing, edited by S. Smith and B. Searle, 126-146. UK: Wiley-Blackwell.

Bryant, L. 2012. "An Assessment of Development Funding for New Housing post-GFC in Queensland, Australia." International Journal of Housing Markets and Analysis 5(2): 118-133.

Bryant L. and Eves, C. 2014. "The link between infrastructure charges and housing affordability in Australia: where is the empirical evidence? Australian Planner, DOI: 10.1080/7293682.2013.877509.

Burke and Associates, 2010. Off the plan property transactions - Issues for accountants \& lawyers, http://www.burkes-law.com/wp-content/uploads/2011/11/Building-Development-Presentation230810.pdf. Last accessed 4 February 2014.

Burke, T. 2012. "The Australian residential market: institutions and actors." In Australia's Unintended Cities: The Impact of Housing on Urban Development. Edited by R. Tomlinson, 3550. Collingwood: CSIRO Publishing.

Cadman, D. and Topping, R. 1995. Property Development. 4th ed. London: Spon Press.

Chandler, D. 2009. Challenging the traditional private sector residential development and building company model, Sydney: City Futures Research Centre.

Clark, L. 2002. Finding a Common Interest: The Story of Dick Dusseldorp and Lend Lease, Cambridge: Cambridge University Press

Coiacetto, E. 2000. "Places Shape Place Shapers? Real Estate developers' Outlooks Concerning Community, Planning and Development Differ between Places", Planning Practice \& Research, 15(4): 353-374.

Coiacetto, E. 2006. "Real Estate Development Industry Structure: Consequences for Urban Planning and Development." Practice \& Research 21(4): 423 - 441.

Coiacetto, E. 2007a. "Residential Sub-Market Targeting by Developer in Brisbane", Urban Policy and Research, 25(2): 257-274.

Coiacetto, E. 2007b. "The Role of the Development Industry in Shaping Social Space: a Conceptual Model", Geographical Research, 45(5): 340-347.

Coiacetto, E. 2009. "Industry Structure in Real Estate Development: Is City Building Competitive?", Urban Policy and Research, 27(2): 117-135.

Coiacetto, E. 2012. Understanding Land Development: A Project-Based Approach, Collingwood, CSIRO Publishing.

Dalton, T., Hurley, J., Gharaie, E., Wakefield, R. and Horne, R. 2013. Australian suburban house building: industry organisation, practices and constraints, Final Report No.213. Melbourne: AHURI.

Daly, M.T. 1982. Sydney boom, Sydney bust: The city and its property market, 1850-1981 Sydney; Allen \& Unwin.

de Maddalena, G. and Schuster, M. 2005. Go south: the Tübingen model, trans. Geoffrey Steinherz, Tübingen: Ernst Wasmuth.

Dolin, A. London, G. and McQuoid, K. 1992. Sector 4 Housing: a Concept to Address the Need for Urban Consolidation and Better Communities - A Report to The Office of The Family, Government of Western Australia. West Perth: The Rowland Company.

Dowling, R. 2005. "Residential Building in Australia, 1993-2003", Urban Policy and Research, 23(4): 447-464. 
Eslake, S. 2013. Saul Eslake: 50 Years of Housing Failure, Address to the 122nd Annual Henry George Commemorative Dinner The Royal Society of Victoria, Melbourne 2nd, September.

Forlee, R. 2012. Australian Residential Property Development: A Step-by-Step Guide for Investors. Hoboken: John Wiley \& Sons.

Fuchs, D. and Jutta, O. 2000. Bauen in der Gruppe: Kostengünstig, Innovativ, Ökologisch, [Building in Groups: Inexpensive, Innovative, Ecologically Sustainable]. München: Callwey.

Goodman, R. Buxton, M. Chhetri, P. Taylor, E. and Wood, G. 2010. Planning and the Characteristics of Housing Supply in Melbourne, Final Report No. 157. Melbourne: AHURI

Gurran, N. Ruming, K. and Randolph, B. 2009 Counting the Costs: Planning Requirements, Infrastructure Contributions, and Residential Development in Australia. AHURI Final Report No. 140, Melbourne: AHURI.

Housing Supply and Affordability Reform Working Party (HSAR) 2012. Housing Supply and Affordability Report, Canberra: COAG.

Kent, T. 2011. Property Development Finance Post-GFC, presentation for Ashe Morgan Winthrop, $26 \quad$ August, Brisbane. http://www.qld.api.org.au/assets/media_library/000/000/206/original.pdf?1314684262, accessed 27 September 2013

Krämer, S. and Gerd, K. 2009. Städte und Baugemeinschaften, [Cities and Construction Sector Communities]. Stuttgart and Zürich: Wüstenrot Stiftung, Ludwigsburg, and Karl Krämer Verlag.

MCU (Major Cities Unit) 2010. State of Australian Cities 2010. Canberra: Commonwealth of Australia.

Millington, A. 2013. Property Development, Hoboken: Taylor and Francis.

NHSC (National Housing Supply Council) 2013. Housing Supply and Affordability Issues 2012-13. Canberra: Commonwealth of Australia.

Newton, P. and Glackin, S. 2014. "Understanding infill: towards a new policy and practice for urban regeneration in the established suburbs of Australia's cities". Urban Policy and Research. DOI: 10.1080/08111146.2013.877389

Pallisco, M. 2014. 'Eye-opener sale' in Capital Gains, The Age, Saturday 19th, pages 14-15.

Peiser, R. and Hamilton, D 2012. Professional Real Estate Development The ULI Guide to the Business, 3rd ed. Chicago: Urban Land Institute.

Phan, T. Peterson, J. and Chandra, S. 2008. "Urban Infill: Extent and Implications in the City of Monash." People and Place 16(4): 23-31.

PCA (Property Council of Australia) 2012. Making the Numbers Stack Up - A Study into Major Residential Urban Renewal in Melbourne, Melbourne: PCA.

Rijavec, I. 2013. Why Citiniche? February $6^{\text {th }}$, http://citiniche.com.au/blog/why-citiniche/

Rowley, S. and Phibbs, P. 2012. Delivering diverse and affordable housing on infill development sites, Final Report No.193. Melbourne: AHURI.

Rowley, S., Costello, G., Higgins, D. and Phibbs, P. 2014. The financing of residential development in Australia, AHURI Final Report No. 219, Melbourne: AHURI.

Ruming, K. 2010. "Developer Typologies in Urban Renewal in Sydney: Recognising the Role of Informal Associations between Developers and Local Government." Urban Policy and Research 28(1): 65-83.

Sharam, A. 2012. 'Smart Housing', Presentation to the Housing Melbourne Symposium, 7th November, Office of the Victorian Government Architect, Swinburne University and the Princes Foundation, National Gallery of Victoria. http://www.ovga.vic.gov.au/images/Alves_Sharam_McShane_words.pdf. 
Szafraniec, J. and Hollaway, A 2012. The Unplanned Source of Housing Supply: What Drives Incremental Infill Housing Development. Melbourne: SGS Economics \& Planning.

Thomas, P. 2010. Profit from Property: Your Step-by-Step Guide to Successful Real Estate Development, John Wiley \& Sons.

UDIA, 2011. The 2011 UDIA state of the land report, Canberra: Urban Development Institute of Australia

Urbis. 2012. Housing Supply Responses to Change in Affordability, Final Report, Canberra: NHSC.

Weaver, P., and Kingsley, C. 2001. Banking and Lending Practice. 4th ed. Sydney: Australia Lawbook Co.

Weerasooria, W.S. 1998, Bank Lending and Securities in Australia. Sydney: Butterworths.

Williams, T. and Macken, S. 2012. Homes for All, Sydney: The McKell Institute.

Wilkinson, S. 2008. Property Development, Hoboken: Taylor \& Francis.

Wing, H., Norman, D. and Orsmond, D. 2012. Supply-side Issues in the Housing Sector, in The Bulletin, September Quarter, Sydney: Reserve Bank of Australia, pp11-19. http://www.rba.gov.au/publications/bulletin/2012/sep/2.html.

Woodcock, I., Dovey, K., Wollan, S., and Robertson, I 2011. Speculation and Resistance: Constraints on Compact City Policy Implementation in Melbourne, Urban Policy and Research, 29(4): 343-363.

Worthington, A., 2011. The quarter century record on housing affordability, affordability drivers, and government policy responses in Australia, Brisbane: Griffith Business School. 